Archive for

Organic Chemistry
Arkivoc 2018, part vii, 0-0 to be inserted by editorial office

\title{
Application of Appel reaction to the primary alcohol groups of fructooligosaccharides: Synthesis of 6,6',6"-trihalogenated 1-kestose derivatives
}

\author{
Zetryana Puteri Tachrim, ${ }^{a}$ Tadashi Nakamura, ${ }^{\mathrm{b}}$ Yasuko Sakihama, ${ }^{\mathrm{a}}$ Yasuyuki Hashidoko, ${ }^{\mathrm{a}}$ and Makoto \\ Hashimoto*a
}

${ }^{a}$ Division of Applied Science, Graduate School of Agriculture, Hokkaido University, Sapporo, Japan

${ }^{b}$ Department of Agricultural and Life Science, Obihiro University of Agriculture and Veterinary Medicine, Obihiro, Japan

Email: hasimoto@abs.agr.hokudai.ac.jp

Received 07-30-2018

Accepted 10-19-2018

Published on line 11-18-2018

\section{Abstract}

1-kestose (O-B-D-fructofuranosyl-( $2 \rightarrow 1)-6$-D-fructofuranosyl-( $2 \rightarrow 1)-\alpha$-D-glucopyranoside) is a potential short chain fructooligosaccharide with an inulin-type skeleton. Halogenation of 1-kestose was conducted via the Appel reaction with the use of carbon tetrahalide $\left(\mathrm{CBr}_{4}\right.$ or $\left.\mathrm{CCl}_{4}\right)$ and triphenylphosphine, which was then followed by conventional acetylation. The per- $O$-acetylated form of $6,6^{\prime}, 6^{\prime \prime}$-trihalogenated derivatives of 1 kestose were conveniently isolated. Further deprotection of the per-O-acetylated form resulted in 6-, 6'-, and $6^{\prime \prime}$-trihalogenated derivatives. The structure elucidation by one- and two-dimensional nuclear magnetic resonance established that halogenations are specific at the 6-, 6'-, and 6'"-position of 1-kestose primary alcohols.
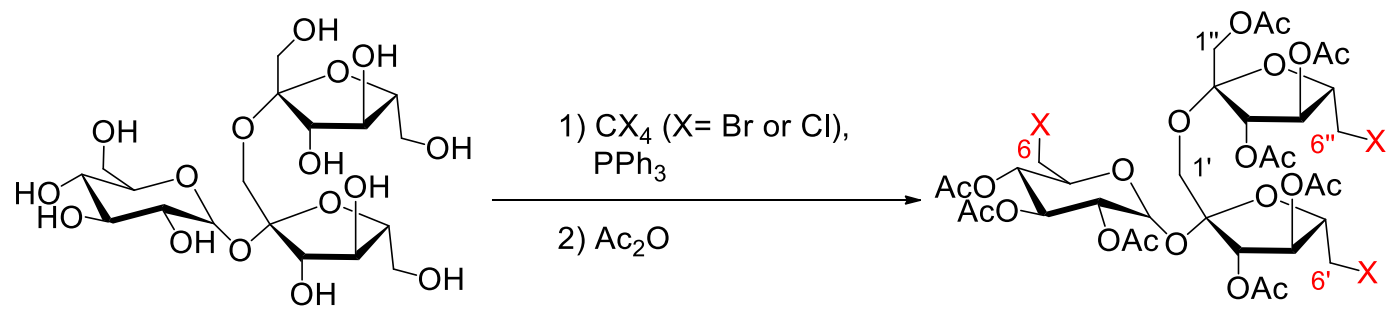

Keywords: Appel reaction; nuclear magnetic resonance (NMR); primary alcohol; regioselective halogenations; 1-kestose; fructooligosaccharides 


\section{Introduction}

Inulin-type short-chain fructooligosaccharides (FOS) are fructose oligomers that consist of a terminal glucosyl unit and two to five fructosyl units. They are recognized as prebiotic indigestible organosaccharides ${ }^{1}$ and due to this property, FOS demand has been increasing in the food industry. ${ }^{2}$ 1-Kestose $(\mathbf{1}$, Figure 1$)$ is one of FOS that has a $\mathbf{6}$-D-fructofuranosyl group on 0-1 of the D-fructosyl moiety of sucrose (2, Figure 1). 1-Kestose $\mathbf{1}$ is naturally found in honey and some plants belonging to the Amaryllidaceae family. ${ }^{3-5}$ The interest in 1-kestose 1 , as a low-calorie food ingredient, continues to increase due to its sweetening power. FOS syrup enriched by 1-kestose 1 can be used as alternative sweetener for diabetics. ${ }^{6}$ To produce 1-kestose 1 , the enzyme derived from the leaves of sugar beets have demonstrated transfructosylation activity in the present of sucrose 2; thus, the products of transfer were mainly 1-kestose 1 with smaller proportions of other oligosaccharides. ${ }^{7}$ Commercial cellulolytic enzymes have also been studied for preparation of FOS with high 1-kestose concentrations. $^{2}$
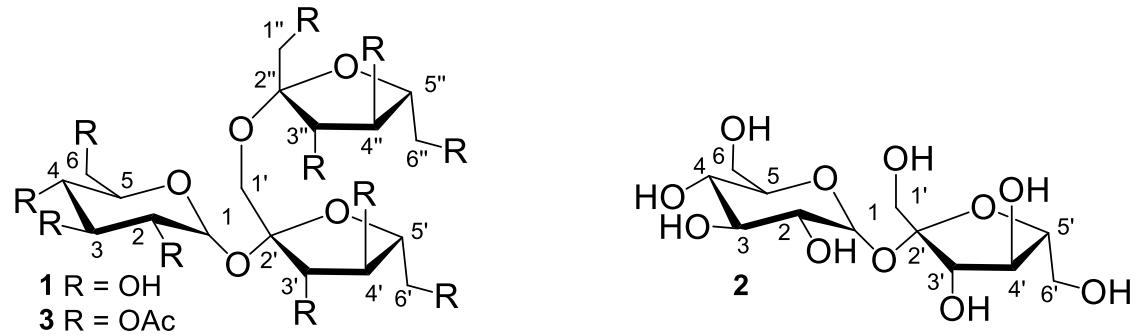

Figure 1. Structure of 1-kestose (1), sucrose (2), and undecaacetate of 1-kestose (3).

Since the specific substitution of sucrose primary hydroxyl groups by chloride enhances the sweetness activity, ${ }^{8}$ halogenated carbohydrate derivatives can potentially be used as an alternative sweetener. The direct halogenation of the hydroxyl groups of carbohydrate is a convenient method to achieve the synthesis of halogenated carbohydrate on its primary hydroxyl groups. Thus, selective halogenation for carbohydrate has become an area of interest in organic chemistry. The Appel reaction is one of the most important reactions used to convert the primary hydroxyl group into a halo methylene group in the presence of triphenylphosphine and carbon tetrahalide. ${ }^{9}$ This method was used for selective halogenation of primary hydroxyl groups over secondary hydroxyl groups in carbohydrates. Halogenation (particularly for chlorination and bromination) of primary alcohols of sucrose $2^{10}$-the main precursor for enzyme-catalyst generation of 1kestose 1 -has been studied since the $1970 \mathrm{~s}^{11}$, but the reactivity of primary hydroxyl groups attained using the Appel reaction has not been completely identified due to limitation of structure analysis. Recently, we reported that sucrose $\mathbf{2}$ can be selectively brominated and chlorinated using the Appel reaction at only the 6and 6 '- position with no halogenation at 1'-position supported by one- and two-dimensional (1D and 2D, respectively) NMR analysis. ${ }^{12}$ As for trisaccharide modification, halogenation of the primary hydroxyl groups of raffinose (O- $\alpha$-D-galactopyranosyl-(1 $\rightarrow 6)-\alpha$-D-glucopyranosyl-(1 $\rightarrow 2)-6$-D-fructofuranoside) has been reported previously. ${ }^{13}$ Raffinose reacted with sulfuryl chloride and the authors found that the chlorinated proportion at the primary position was followed by chlorination at the 4-position of the galactopyranosyl moiety secondary alcohols. To date, no study has been attempted to substitute primary alcohols of FOS using halogens. In midst of FOS, 1-kestose 1 has shown relatively high sweetness activity and is already commercially available. Therefore, its primary alcohol modification would potentially increase the synthesis of alternative sweeteners. 
In this study, we aimed to synthesize halogenated 1-kestose 1 at the primary position by using the Appel reaction to comprehensively study the structure elucidation supported by 1D and 2D NMR analysis.

\section{Results and Discussion}

Direct substitution of 1-kestose 1 with 4.7 equiv. carbon tetrahalide (bromide or chloride) and 9.1 equiv. triphenylphosphine at $70{ }^{\circ} \mathrm{C}$ for two hours (Scheme 1) produced a complex mixture with complicated ${ }^{1} \mathrm{H}-\mathrm{NMR}$ analysis due to observation of overlap signals, especially the modified primary centers. The mixture was separated after conventional acetylation. Further purification was conducted using an ether and hexane system as the representative mobile phase to isolate halogenated carbohydrate. The ethyl acetate or dichloromethane system cannot be used for the halogenated proportion. ${ }^{12}$ The mixture produced halogenated 1-kestose derivatives in the pre-O-acetylated form (bromination $\mathbf{4}$ and chlorination $\mathbf{5}$, Scheme 1).
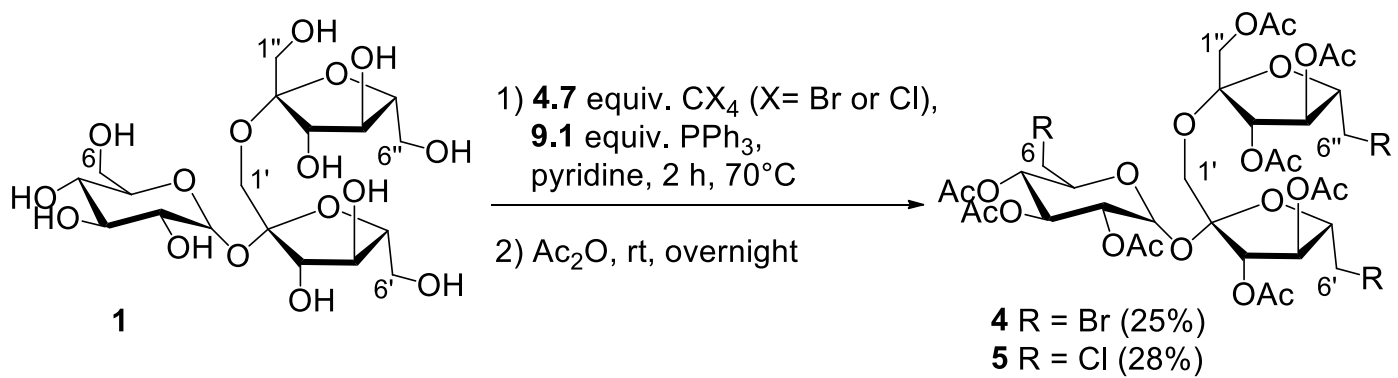

Scheme 1. Halogenation of 1-kestose (1) via Appel reaction with $\mathrm{Ph}_{3} \mathrm{P}$ and carbon tetrahalide to produce pre$\mathrm{O}$-acetylated form of halogenated 1-kestose derivatives (bromination $\mathbf{4}$ and chlorination $\mathbf{5}$ ).

The ${ }^{1} \mathrm{H}$ NMR analysis for peracetylated 4 and 5 showed two regions that contribute to the proton resonance of aliphatic sugar groups in the downfield region and halogenated methylene groups located in the upfield region. Based on ${ }^{13} \mathrm{C}$ NMR, three halogenated methylene in the upfield region were easily determined in the halogenated proportion in the 1-kestose derivatives, but the halogenated position remained unclear. Therefore, 2D NMR (COSY, HETCOR, HMQC, HMBC, NOESY, and TOCSY) was used to determine the halogenated position. For this purpose, $\mathrm{CDCl}_{3}^{12,14}$ was used as the solvent to increase the visibility of the spin system during the analysis. Undecaacetate 1-kestose ${ }^{3,15}$ (3, Figure 1, Figures SM-17-24 for detail NMR analysis and Table SM-1 for 1D and 2D NMR and comparison of structure elucidation with the literature) was identified and used to understand the sugar skeleton of halogenated 1-kestose derivatives.

During brominated position investigation of the 1-kestose derivative, ${ }^{1} \mathrm{H}-\mathrm{NMR}$ of compound 4 showed eight proton signals in the upfield region. The excess of two protons corresponds to the $\mathrm{H}-1^{\prime}$ glycosidic bond of $O-B$-D-fructofuranosyl-(2 $\rightarrow 1)-8$-D-fructofuranosyl, which showed considerable geminal coupling with a typical pair of doublets at $\delta=3.79$ and $3.73 \mathrm{ppm}(J=10.3 \mathrm{~Hz})$. The correlation between $\mathrm{H}-1^{\prime}$ a and $\mathrm{H}-1^{\prime} \mathrm{b}$ with $\mathrm{C}-2^{\prime}$ in HMBC, supported by HETCOR and HMQC, distinguished this spin system (Figures SM-4-6). The same tendency was also demonstrated by the undecaacetate of 1-kestose 3, which supported the glycosidic bond signals. The additional six proton signals in the upfield region highlighted the specific brominated proportion of compound 4. A clear pair of doublets at $\delta=3.54$ and $3.40 \mathrm{ppm}(J=2.3,11.5 \mathrm{~Hz}$ and $J=6.3,11.5 \mathrm{~Hz}$, respectively) were observed by ${ }^{1} \mathrm{H}-\mathrm{NMR}$. The geminal coupling for these spins systems indicated the brominated methylene of the glucose ring at the 6-position, which was easily distinguished by its correlation with $\mathrm{H}-5$ in COSY and with 
$\mathrm{H}-4$ and H-5 in TOCSY (Figures SM-3 and SM-8). Moreover, the carbon brominated terminal at the 6-position $(\delta=31.1 \mathrm{ppm}$ ) was also identified, as supported by $\mathrm{HMBC}$ analyses. The observation of the long range correlation of C- 6 with H-4 clearly distinguished brominated position which supported by HMQC and HETCOR. The glucose ring's protons and carbons signals were distinguished from fructose rings signals, especially at the C-3, C-4, and C-5 positions, using TOCSY and NOESY (Figures SM-7 and SM-8), which was also, supported by HETCOR, HMQC, and HMBC analyses.

Among 1-kestose's fructose rings, there are three possible primary alcohols at the $6^{\prime}-, 1^{\prime \prime}$, and $6^{\prime \prime}$ position that are readily brominated. The upfield region of ${ }^{1} \mathrm{H}-\mathrm{NMR}$ typically showed two types of doublet at $\delta$ $=3.66 \mathrm{ppm}(J=6.9 \mathrm{~Hz})$ and $3.69 \mathrm{ppm}(J=7.4 \mathrm{~Hz})$, indicating bromination occurred only at the $6^{\prime}-$ and $6^{\prime \prime}-$ position of compound 4, respectively. The correlation between $\mathrm{H}-6^{\prime}$ with $\mathrm{H}-5^{\prime}$ in COSY and $\mathrm{H}-6^{\prime}$ with $\mathrm{H}-4^{\prime}$ and $\mathrm{H}-5^{\prime}$ in TOCSY differentiated the bromination at the $6^{\prime}$-position (Figures SM-3 and SM-8). Similarly, brominated $6^{\prime \prime}$-position of compound 4 showed these particular correlations. The brominated terminal of C- $6^{\prime}$ at $\delta=32.0$ ppm and C-6"at $\delta=32.7$ ppm was determined mostly using HMBC with the observation of a cross peak of these carbons at $\mathrm{H}-4^{\prime}$ and $\mathrm{H}-4^{\prime \prime}$, respectively (Figures SM-6). HETCOR and HMQC coupling between the protons and carbon at the 6'- and/or 6"'-position support the identification of bromination position.

The aliphatic sugar groups between the two fructose rings of compound 4 were differentiated using TOCSY and NOESY, which was supported by COSY, HETCOR, HMQC, and HMBC analyses (Figures SM-3-8). Based on ${ }^{1} \mathrm{H}$ - and ${ }^{13} \mathrm{C}-\mathrm{NMR}$, supported by $2 \mathrm{D}$ NMR analysis, the 1 "-position of compound 4 showed no bromination. The $1^{\prime \prime}$-position of the fructose ring is known to be a neopentyl-like ${ }^{10,12}$ terminal having the least reactive proportion. This phenomena also occurred when sucrose was used. ${ }^{12,16,17}$ According to these approaches, the bromination product of 1-kestose was determined to be $1^{\prime \prime}, 2,3,3^{\prime}, 3^{\prime \prime}, 4,4^{\prime}, 4^{\prime \prime}$-octa-O-acetyl6,6',6'-tribromo-6,6', 6"'-trideoxy-1-kestose (4).

For the chlorination product of $\mathbf{5}$, the spin system in ${ }^{1} \mathrm{H}-\mathrm{NMR}$ showed eight proton signals in the upfield region. Unlike the previous bromination product $\mathbf{4}$ or undecaacetate 1-kestose $\mathbf{3}$, the $\mathrm{H}_{-1} \mathbf{1}^{\prime}$ of compound $\mathbf{5}$ exhibited no geminal coupling and presented as a singlet at $3.75 \mathrm{ppm}$ supported by HMBC, HETCOR, and HMQC, (Figures SM-12-14). The chlorinated proportion at the 6-position was shown as a pair of double doublets at $\delta=3.68$ and $3.57 \mathrm{ppm}(J=2.3,12.0 \mathrm{~Hz}$ and $J=5.7,12.0 \mathrm{~Hz}$, respectively). A clear correlation of this chlorinated methylene of the glucose ring with $\mathrm{H}-5$ in COSY and $\mathrm{H}-4$ and $\mathrm{H}-5$ in TOCSY was observed (Figures SM-11 and SM-16). As for the ${ }^{1} \mathrm{H}$-NMR spin system of $6^{\prime}$ - and $6^{\prime \prime}$-chloro of compound 5 , the overlap signals at $\delta$ = 3.82-3.78 ppm demonstrated its correlation with $\mathrm{H}-5^{\prime}$ and $\mathrm{H}-5^{\prime \prime}$ in COSY and $\mathrm{H}-4^{\prime}, \mathrm{H}-5^{\prime}, \mathrm{H}-4^{\prime \prime}$, and $\mathrm{H}-5^{\prime \prime}$ in TOCSY. The brominated terminal of C $-6^{\prime}$ at $\delta=44.4 \mathrm{ppm}$ and $\mathrm{C}-6^{\prime \prime}$ at $\delta=44.6 \mathrm{ppm}$ highlighted the correlated cross peak of these carbons to $\mathrm{H}-4^{\prime}$ and $\mathrm{H}-4^{\prime \prime}$, respectively. $\mathrm{HMBC}$ strongly distinguished the chlorinated $6^{\prime}-$ and $6^{\prime \prime}$-position of compound 5 (Figures SM-14). These results support that the chlorination product of 1kestose is $1^{\prime \prime}, 2,3,3^{\prime}, 3^{\prime \prime}, 4,4^{\prime}, 4^{\prime \prime}$-octa-O-acetyl-6,6', $6^{\prime}$-trichloro-6,6',6"'-trideoxy-1-kestose (5). As with brominated compound $\mathbf{4}$, chlorinated compound 5 showed no substitution at the $1^{\prime \prime}$-position. The presence of $\mathrm{Br}$ and $\mathrm{Cl}$ isotopic peak in ESI-MS of compounds $\mathbf{4}$ and $\mathbf{5}$ indicated tri-halogenated proportion of 1-kestose, respectively, which supported our analysis.

To synthesize and elucidate the novel 6,6 $6^{\prime} 6^{\prime \prime}$-trihalogenated 1-kestose derivatives, deacetylation was then conducted. Since suitable deacetylation conditions are generated using saturated ammonium in methanol for sucrose, ${ }^{12}$ the undecaacetate of 1-kestose (3) was first tested for deacetylation and produced 1kestose (1) within a satisfactory yield (Figures SM-41-48 for NMR analysis). Deacetylation using other methods, such as sodium methoxide, cannot be used for 1-kestose halogenated derivatives. The per-Oacetylated trihalogenated derivatives of $\mathbf{4}$ and $\mathbf{5}$ were underwent deacetylation, which resulted in compound $\mathbf{6}$ and 7 (Scheme 2). It was complicated to distinguish the halogenated proportion from the deacetylated 
compound 6 and/or 7, since the halogenated methylene spin system at H-6, H-6', and H-6" overlapped with other signals such as $\mathrm{H}-3, \mathrm{H}-1^{\prime}$, and/or $\mathrm{H}-\mathrm{1}^{\prime \prime}$ in ${ }^{1} \mathrm{H}-\mathrm{NMR}$. Hence, the HMBC, HMQC, and HETCOR analyses, supported by COSY, TOCSY, and NOESY, are needed to elucidate the complete structure of deacetylated compounds 6 and 7 (Figures SM-27-32 and SM-35-40). However, all the deacetylated trihalogenated 1kestose derivatives ( 6 and 7 ) structures and halogenation sites were consistent with those in the corresponding per-O-acetylated forms (4 and 5 ).
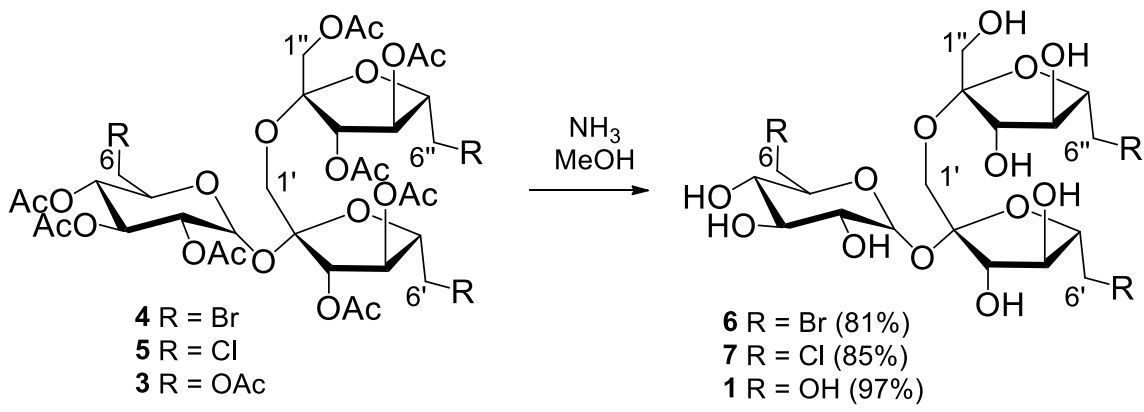

Scheme 2. Deacetylation of per-O-acetylated 1-kestose derivatives (3-5) to result in 1-kestose (1) and deacetylated trihalogenated 1-kestose derivatives (6 and 7 )

\section{Conclusions}

We studied the halogenation of 1-kestose using Appel reactions to synthesize trihalogenated 1-kestose at the 6-, $6^{\prime}$-, and 6"-position. Isolation and structure elucidation were easily completed using the per-O-acetylated form which the 1D and 2D NMR supported the halogenation position. The synthesis and structure elucidation of novel compounds $\mathbf{4}$ and $\mathbf{5}$ contribute to the introduction of primary hydroxyl groups into FOS which can potentially be used as low-calorie sweeteners in the future.

\section{Experimental Section}

General. All reagents used were of analytical grade. NMR spectra were obtained in $\mathrm{CDCl}_{3}$ or $\mathrm{D}_{2} \mathrm{O}$ by $\mathrm{JEOL}$ ECA500 (500 and $125 \mathrm{MHz}$ ) spectrometer (JEOL, Tokyo, Japan). Optical rotations were measured at $23{ }^{\circ} \mathrm{C}$ on a JASCO DIP370 polarimeter (JASCO, Tokyo, Japan). HRMS spectra were obtained with a Waters UPLC ESI-TOF mass spectrometer (Waters, Milford, CT, USA).

General procedure for Appel reaction: bromination. Solution of 1-kestose (1, $0.10 \mathrm{~g}, 0.198 \mathrm{mmol})$ in pyridine $(2 \mathrm{~mL})$ was cooled in an ice bath and treated with triphenylphosphine $(0.47 \mathrm{~g}, 1.8 \mathrm{mmol}, 9.1$ equiv), followed by dropwise addition of a solution of carbon tetrabromide $(0.30 \mathrm{~g}, 0.93 \mathrm{mmol}, 4.7$ equiv) in pyridine $(0.93 \mathrm{~mL})$. The reaction mixture was stirred at $70{ }^{\circ} \mathrm{C}$ for $2 \mathrm{~h}$. After cooling the mixture in an ice bath, acetic anhydride $(3$ $\mathrm{mL}, 32.0 \mathrm{mmol}$ ) and pyridine $(2 \mathrm{~mL})$ were added, and the mixture was stirred overnight at room temperature. The solvent was evaporated and the residue was partitioned between $\mathrm{CH}_{2} \mathrm{Cl}_{2}$ and water. The organic layer was washed with $1 \mathrm{M} \mathrm{HCl}$ and brine, dried over $\mathrm{MgSO}_{4}$, reduced the solvent under high pressure and then purified by column chromatography on silica gel by elution with hexane/diethyl ether (1:6 and 1:10) to yield 
$1^{\prime \prime}, 2,3,3^{\prime}, 3^{\prime \prime}, 4,4^{\prime}, 4^{\prime \prime}$-octa-O-acetyl-6,6',6"'-tribromo-6,6',6"'-trideoxy 1-kestose (4; $\left.0.0516 \mathrm{~g}, 25 \%\right)$ as colorless amorphous mass. $[\alpha]_{D}+22.4\left(c=1.0, \mathrm{CHCl}_{3}\right) .{ }^{1} \mathrm{H}-\mathrm{NMR}\left(500 \mathrm{MHz}, \mathrm{CDCl}_{3}\right) \delta: 5.70\left(1 \mathrm{H}, \mathrm{d}, J_{3^{\prime}, 4^{\prime}} 8.0 \mathrm{~Hz}, \mathrm{H}-3^{\prime}\right), 5.67$ $\left(1 \mathrm{H}, \mathrm{d}, J_{1,2}=4.0 \mathrm{~Hz}, \mathrm{H}-1\right), 5.50\left(1 \mathrm{H}, \mathrm{d}, J_{3^{\prime \prime}, 4^{\prime \prime}} 6.3 \mathrm{~Hz}, \mathrm{H}-3^{\prime \prime}\right), 5.48-5.42\left(2 \mathrm{H}, \mathrm{m}, \mathrm{H}-3, \mathrm{H}-4^{\prime}\right), 5.32\left(1 \mathrm{H}, \mathrm{t}, J_{3^{\prime \prime}, 4^{\prime \prime}} 6.3 \mathrm{~Hz}\right.$, H-4'), $5.03\left(1 \mathrm{H}, \mathrm{t}, J_{3,4} 9.7 \mathrm{~Hz}, \mathrm{H}-4\right), 4.95\left(1 \mathrm{H}, \mathrm{dd}, J_{1,2} 4.0 \mathrm{~Hz}, J_{2,3} 10.3 \mathrm{~Hz}, \mathrm{H}-2\right), 4.35-4.28\left(2 \mathrm{H}, \mathrm{m}, \mathrm{H}-5, \mathrm{H}-5^{\prime}\right), 4.24$ $\left(2 \mathrm{H}, \mathrm{s}, \mathrm{H}-1^{\prime \prime}\right), 4.22-4.19\left(1 \mathrm{H}, \mathrm{m}, \mathrm{H}-5^{\prime \prime}\right), 3.79\left(1 \mathrm{H}, \mathrm{d}, J_{1^{\prime} \mathrm{a}, 1^{\prime} \mathrm{b}} 10.3 \mathrm{~Hz}, \mathrm{H}-1^{\prime} \mathrm{a}\right), 3.73\left(1 \mathrm{H}, \mathrm{d}, J_{1^{\prime} \mathrm{a}, 1^{\prime} b} 10.3 \mathrm{~Hz}, \mathrm{H}-1^{\prime} b\right), 3.69$ $\left(2 \mathrm{H}, \mathrm{d}, J_{5^{\prime \prime}, 6^{\prime \prime}} 7.4 \mathrm{~Hz}, \mathrm{H}-6^{\prime \prime}\right), 3.66\left(2 \mathrm{H}, \mathrm{d}, J_{5^{\prime}, 6^{\prime}} 6.9 \mathrm{~Hz}, \mathrm{H}-6^{\prime}\right), 3.54\left(1 \mathrm{H}, \mathrm{dd}, J_{5,6 \mathrm{a}} 2.3 \mathrm{~Hz}, J_{6 a, 6 b} 11.5 \mathrm{~Hz}, \mathrm{H}-6 \mathrm{a}\right), 3.40(1 \mathrm{H}$, dd, $\left.J_{5,6 b} 6.3 \mathrm{~Hz}, J_{6 a, 6 b} 11.5 \mathrm{~Hz}, \mathrm{H}-6 \mathrm{~b}\right), 2.16-2.15\left(6 \mathrm{H}, \mathrm{m}, 2 \times \mathrm{CH}_{3}\right), 2.14\left(3 \mathrm{H}, \mathrm{s}, \mathrm{CH}_{3}\right), 2.11\left(3 \mathrm{H}, \mathrm{s}, \mathrm{CH}_{3}\right), 2.09-2.07$ $\left(9 \mathrm{H}, \mathrm{m}, 3 \times \mathrm{CH}_{3}\right), 2.02\left(3 \mathrm{H}, \mathrm{s}, \mathrm{CH}_{3}\right) \mathrm{ppm} .{ }^{13} \mathrm{C}-\mathrm{NMR}\left(125 \mathrm{MHz}, \mathrm{CDCl}_{3}\right)$ 8: 170.2, 170.0, 170.0, 169.8, 169.5 (C=O), 103.8 (C-2'), 103.1 (C-2"), 90.1 (C-1), 80.7 (C-5"), 79.8 (C-5'), 78.1 (C-4"), 77.2 (C-3"), 76.4 (C-4'), 75.8 (C-3'), 70.8 (C-4), 69.7 (C-2), 69.3 (C-3 \& C-5), 62.0 (C-1"'), 61.5 (C-1'), 32.7 (C-6"), 32.0 (C-6'), 31.1 (C-6), 20.8, 20.8, 20.7, 20.8, 20.6, 20.5, 20.5, $20.5\left(\mathrm{CH}_{3}\right)$ ppm. HRMS (ESI): calcd. for $\mathrm{C}_{34} \mathrm{H}_{45} \mathrm{O}_{21} \mathrm{Br}_{3} \mathrm{Na}$ 1050.9881, $1052.9860[\mathrm{M}+$ $\mathrm{Na}]^{+}$; found 1050.9899, 1052.9880.

Chlorination. Chlorination was similar to bromination as described above, except carbon tetrabromide in

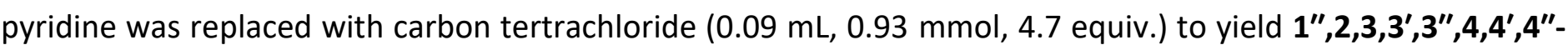
octa-O-acetyl-6,6',6"-trichloro-6,6',6"-trideoxy-1-kestose (5; $0.0514 \mathrm{~g}, 28 \%)$ as colorless amorphous mass. $[\alpha]_{D}+26.6\left(\mathrm{c}=1.0, \mathrm{CHCl}_{3}\right) .{ }^{1} \mathrm{H}-\mathrm{NMR}\left(500 \mathrm{MHz}, \mathrm{CDCl}_{3}\right) \delta: 5.70-5.66\left(2 \mathrm{H}, \mathrm{m}, \mathrm{H}-1, \mathrm{H}-3^{\prime}\right), 5.50\left(1 \mathrm{H}, \mathrm{d}, \mathrm{J}_{3^{\prime \prime}, 4^{\prime \prime}} 6.3 \mathrm{~Hz}\right.$, $\left.\mathrm{H}-3^{\prime \prime}\right), 5.48-5.41\left(2 \mathrm{H}, \mathrm{m}, \mathrm{H}-3, \mathrm{H}-4^{\prime}\right), 5.33\left(1 \mathrm{H}, \mathrm{t}, J_{3^{\prime \prime}, 4^{\prime \prime}}=6.3 \mathrm{~Hz}, \mathrm{H}-4^{\prime \prime}\right), 5.06\left(1 \mathrm{H}, \mathrm{t}, J_{3,4}=9.7 \mathrm{~Hz}, \mathrm{H}-4\right), 4.93(1 \mathrm{H}, \mathrm{dd}$, $\left.J_{1,2} 3.7 \mathrm{~Hz}, J_{2,3} 10.6 \mathrm{~Hz}, \mathrm{H}-2\right), 4.38-4.32(1 \mathrm{H}, \mathrm{m}, \mathrm{H}-5), 4.28-4.22\left(3 \mathrm{H}, \mathrm{m}, \mathrm{H}-1^{\prime \prime}, \mathrm{H}-5^{\prime}\right), 4.17\left(1 \mathrm{H}, \mathrm{q}, J_{5^{\prime \prime}, 6^{\prime \prime}} 6.5 \mathrm{~Hz}, \mathrm{H}-\right.$ $\left.5^{\prime \prime}\right), 3.82-3.78\left(4 \mathrm{H}, \mathrm{m}, \mathrm{H}-6^{\prime}, \mathrm{H}-6^{\prime \prime}\right), 3.75\left(2 \mathrm{H}, \mathrm{s}, \mathrm{H}-1^{\prime}\right), 3.68\left(1 \mathrm{H}, \mathrm{dd}, J_{5,6 \mathrm{a}} 2.3 \mathrm{~Hz}, J_{6 a, 6 b} 12.0 \mathrm{~Hz}, \mathrm{H}-6 \mathrm{a}\right), 3.57(1 \mathrm{H}, \mathrm{dd}$, $\left.J_{5,6 b} 5.7 \mathrm{~Hz}, J_{6 a, 6 b} 12.0 \mathrm{~Hz}, \mathrm{H}-6 \mathrm{~b}\right), 2.16\left(3 \mathrm{H}, \mathrm{s}, \mathrm{CH}_{3}\right), 2.15-2.13\left(6 \mathrm{H}, \mathrm{m}, 2 \times \mathrm{CH}_{3}\right), 2.11\left(3 \mathrm{H}, \mathrm{s}, \mathrm{CH}_{3}\right), 2.09\left(3 \mathrm{H}, \mathrm{s} \mathrm{CH}_{3}\right)$, $2.08\left(3 \mathrm{H}, \mathrm{s}, \mathrm{CH}_{3}\right), 2.07\left(3 \mathrm{H}, \mathrm{s}, \mathrm{CH}_{3}\right), 2.02\left(3 \mathrm{H}, \mathrm{s}, \mathrm{CH}_{3}\right) .{ }^{13} \mathrm{C}-\mathrm{NMR}\left(125 \mathrm{MHz}, \mathrm{CDCl}_{3}\right)$ \&: 170.2, 170.1, 170.0, 170.0, 169.7, 169.5 (C=O), 103.8 (C-2'), 103.1 (C-2"), 90.0 (C-1), 80.6 (C-5"), 79.9 (C-5'), 77.2 (C-4"), 76.9 (C-3"), 75.7 C-4'), $75.5\left(\mathrm{C}-3^{\prime}\right), 69.8(\mathrm{C}-5), 69.7$ (C-2 \& C-4), $69.4(\mathrm{C}-3), 62.2\left(\mathrm{C}-1^{\prime \prime}\right), 61.6\left(\mathrm{C}-1^{\prime}\right), 44.6\left(\mathrm{C}-6^{\prime \prime}\right), 44.4\left(\mathrm{C}-6^{\prime}\right), 43.2(\mathrm{C}-$ 6), 20.8, 20.7, 20.7, 20.6, 20.5, $20.5\left(\mathrm{CH}_{3}\right)$ ppm. HRMS (ESI): calcd. for $\mathrm{C}_{34} \mathrm{H}_{45} \mathrm{O}_{21} \mathrm{Cl}_{3} \mathrm{Na} 919.1387[\mathrm{M}+\mathrm{Na}]^{+}$; found 919.1395 .

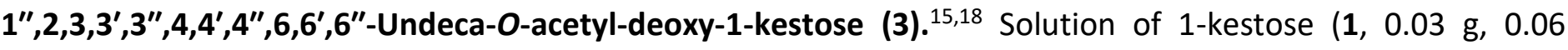
$\mathrm{mmol})$ in pyridine $(15 \mathrm{~mL})$ was treated with acetic anhydride $(1 \mathrm{~mL}, 10.7 \mathrm{mmol})$, and the mixture was stirred overnight at room temperature. The solvent was removed under reduced pressure and subjected to column chromatography on silica gel by elution with chloroform to yield $3(0.055 \mathrm{~g}, 96 \%)$ as a colorless liquid. [ $\alpha]_{D}+$ 30.2 (c = 1.0, $\mathrm{CHCl}_{3}$ ); Ref. ${ }^{16}[\alpha]_{\mathrm{D}}+31.8$ (c = 3.7, $\left.\mathrm{CHCl}_{3}\right) .{ }^{1} \mathrm{H}-\mathrm{NMR}\left(500 \mathrm{MHz}, \mathrm{CDCl}_{3}\right) \delta: 5.75\left(1 \mathrm{H}, \mathrm{d}, J_{1,2} 3.4 \mathrm{~Hz}, \mathrm{H}-1\right)$, $5.69\left(1 \mathrm{H}, \mathrm{d}, J_{3^{\prime}, 4^{\prime}} 8.0 \mathrm{~Hz}, \mathrm{H}-3^{\prime}\right), 5.48\left(1 \mathrm{H}, \mathrm{d}, J_{3^{\prime \prime}, 4^{\prime \prime}} 6.9 \mathrm{~Hz}, \mathrm{H}-3^{\prime \prime}\right), 5.46\left(1 \mathrm{H}, \mathrm{t}, J_{3^{\prime}, 4^{\prime}} 8.0 \mathrm{~Hz}, \mathrm{H}-4^{\prime}\right), 5.42\left(1 \mathrm{H}, \mathrm{t}, J_{3,4} 9.7\right.$ $\mathrm{Hz}, \mathrm{H}-3), 5.34\left(1 \mathrm{H}, \mathrm{t}, J_{3^{\prime \prime}} 4^{\prime \prime} 6.9 \mathrm{~Hz}, \mathrm{H}-4^{\prime \prime}\right), 5.08\left(1 \mathrm{H}, \mathrm{t}, J_{3,4} 9.7 \mathrm{~Hz}, \mathrm{H}-4\right), 4.91\left(1 \mathrm{H}, \mathrm{dd}, J_{1,2} 3.4 \mathrm{~Hz}, J_{2,3} 10.3 \mathrm{~Hz}, \mathrm{H}-2\right)$, 4.39-4.33 (3H, m, H-5, H-6") , 4.33-4.24 (3H, m, H-6a, H-6'), 4.24-4.20 (3H, m, H-1"', H-5'), 4.20-4.14 (2H, m, H-

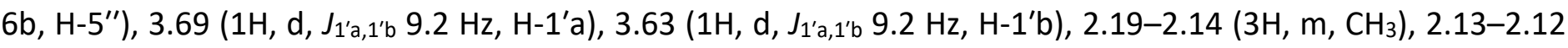
$\left(6 \mathrm{H}, \mathrm{m}, 2 \times \mathrm{CH}_{3}\right), 2.11-2.09\left(15 \mathrm{H}, \mathrm{m}, 5 \times \mathrm{CH}_{3}\right), 2.06\left(3 \mathrm{H}, \mathrm{s}, \mathrm{CH}_{3}\right), 2.04\left(3 \mathrm{H}, \mathrm{s}, \mathrm{CH}_{3}\right), 2.01\left(3 \mathrm{H}, \mathrm{s}, \mathrm{CH}_{3}\right) \mathrm{ppm} .{ }^{13} \mathrm{C}-$

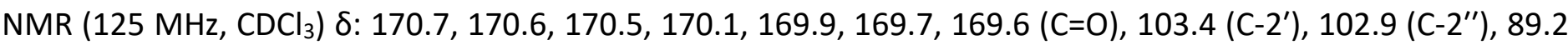
(C-1), $78.4\left(\mathrm{C}-5^{\prime \prime}\right), 77.8\left(\mathrm{C}-5^{\prime}\right), 76.5\left(\mathrm{C}-3^{\prime \prime}\right), 75.5\left(\mathrm{C}-4^{\prime \prime}\right), 74.9\left(\mathrm{C}-3^{\prime}\right), 73.7\left(\mathrm{C}-4^{\prime}\right), 70.0$ (C-2), 69.8 (C-3), 68.2 (C-5), $68.2(\mathrm{C}-4), 63.7\left(\mathrm{C}-6^{\prime \prime}\right), 63.2\left(\mathrm{C}-6^{\prime}\right), 62.7\left(\mathrm{C}-1^{\prime \prime}\right), 62.2\left(\mathrm{C}-1^{\prime}\right), 61.7(\mathrm{C}-6), 20.8,20.7,20.7,20.6,20.6,20.5\left(\mathrm{CH}_{3}\right)$ ppm. HRMS (ESI): calcd. for $\mathrm{C}_{40} \mathrm{H}_{54} \mathrm{O}_{27} \mathrm{Na} 989.2750[\mathrm{M}+\mathrm{Na}]^{+}$; found 989.2797.

General procedure for deacetylation of per-0-acetylated halodeoxy-1-kestose derivatives. Solutions of per$O$-acetylated halodeoxy-1-kestose derivatives (3-5, $0.05 \mathrm{~g}$ ) in $3 \mathrm{~mL}$ dry methanol were treated with $1.5 \mathrm{~mL}$ saturated ammonia in methanol and stirred overnight at room temperature. The solvent was removed under reduced pressure and subjected to column chromatography on silica gel (pre-washed by methanol) by elution 
with methanol/chloroform (3:1). The method produced the corresponding halodeoxy-1-kestose derivatives 1, 6, and 7.

1-Kestose ${ }^{3}$ (1, 0.034 g, 97\%). ${ }^{1} \mathrm{H}-\mathrm{NMR}\left(500 \mathrm{MHz}, \mathrm{D}_{2} \mathrm{O}\right) \delta: 5.37\left(1 \mathrm{H}, \mathrm{d}, J_{1,2} 4.0 \mathrm{~Hz}, \mathrm{H}-1\right), 4.22\left(1 \mathrm{H}, \mathrm{d}, J_{3^{\prime}, 4^{\prime}} 8.6 \mathrm{~Hz}\right.$, H-3'), $4.13\left(1 \mathrm{H}, \mathrm{d}, J_{3^{\prime \prime}, 4^{\prime \prime}} 8.6 \mathrm{~Hz}, \mathrm{H}-3^{\prime \prime}\right), 4.02\left(1 \mathrm{H}, \mathrm{t}, J_{3^{\prime \prime}, 4^{\prime \prime}} 8.6 \mathrm{~Hz}, \mathrm{H}-4^{\prime \prime}\right), 3.98\left(1 \mathrm{H}, \mathrm{t}, J_{3^{\prime}, 4^{\prime}} 8.6 \mathrm{~Hz}, \mathrm{H}-4^{\prime}\right), 3.83-3.80$ $\left(2 \mathrm{H}, \mathrm{m}, \mathrm{H}-5^{\prime}, \mathrm{H}-5^{\prime \prime}\right), 3.79-3.71\left(8 \mathrm{H}, \mathrm{m}, \mathrm{H}-1^{\prime} \mathrm{a}, \mathrm{H}-5, \mathrm{H}-6, \mathrm{H}-6^{\prime}, \mathrm{H}-6^{\prime \prime}\right), 3.70-3.60\left(4 \mathrm{H}, \mathrm{m}, \mathrm{H}-3, \mathrm{H}-1^{\prime} \mathrm{b}, \mathrm{H}-1^{\prime \prime}\right), 3.48(1 \mathrm{H}$, dd, $\left.J_{1,2} 4.0 \mathrm{~Hz}, J_{2,3} 9.7, \mathrm{H}-2\right), 3.41\left(1 \mathrm{H}, \mathrm{t}, J_{3,4} 9.7 \mathrm{~Hz}, \mathrm{H}-4\right)$ ppm. ${ }^{13} \mathrm{C}-\mathrm{NMR}(125 \mathrm{MHz}, \mathrm{D} 2 \mathrm{O}) \delta: 104.2$ (C-2"), 103.7 (C2'), 92.9 (C-1), $81.6\left(\mathrm{C}-5^{\prime}\right), 81.5\left(\mathrm{C}-5^{\prime \prime}\right), 77.0\left(\mathrm{C}-3^{\prime} \& \mathrm{C}-3^{\prime \prime}\right), 74.9\left(\mathrm{C}-4^{\prime \prime}\right), 74.2\left(\mathrm{C}-4^{\prime}\right), 73.0$ (C-3), 72.8 (C-5), 71.6 (C2), 69.6 (C-4), $62.7\left(\mathrm{C}-6^{\prime \prime}\right), 62.6\left(\mathrm{C}-6^{\prime}\right), 61.3\left(\mathrm{C}-1^{\prime}\right), 60.8\left(\mathrm{C}-1^{\prime \prime}\right), 60.5$ (C-6) ppm.

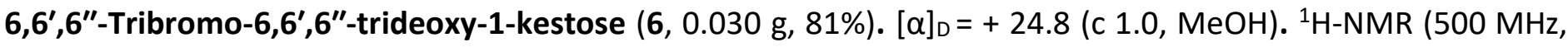
$\left.\mathrm{D}_{2} \mathrm{O}\right) \delta: 5.36\left(1 \mathrm{H}, \mathrm{d}, J_{1,2} 4.0 \mathrm{~Hz}, \mathrm{H}-1\right), 4.27\left(1 \mathrm{H}, \mathrm{d}, J_{3^{\prime}, 4^{\prime}} 8.6 \mathrm{~Hz}, \mathrm{H}-3^{\prime}\right), 4.16\left(1 \mathrm{H}, \mathrm{d}, J_{3^{\prime \prime}, 4^{\prime \prime}} 8.6 \mathrm{~Hz}, \mathrm{H}-3^{\prime \prime}\right), 4.09-4.05$ $\left(2 \mathrm{H}, \mathrm{m}, \mathrm{H}-4^{\prime}, \mathrm{H}-4^{\prime \prime}\right), 4.04-3.98\left(3 \mathrm{H}, \mathrm{m}, \mathrm{H}-5, \mathrm{H}-5^{\prime}, \mathrm{H}-5^{\prime \prime}\right), 3.87\left(1 \mathrm{H}, \mathrm{d}, \mathrm{J}_{1^{\prime} \mathrm{a}, 1^{\prime} \mathrm{b}} 10.3 \mathrm{~Hz}, \mathrm{H}-1^{\prime} \mathrm{a}\right), 3.79-3.72(3 \mathrm{H}, \mathrm{m}, \mathrm{H}-$ $\left.6 a, H-6^{\prime \prime}\right), 3.72-3.65\left(5 \mathrm{H}, \mathrm{m}, \mathrm{H}-1^{\prime} \mathrm{b}, \mathrm{H}-1^{\prime \prime}, \mathrm{H}-6 \mathrm{~b}, \mathrm{H}-3\right), 3.64-3.59\left(2 \mathrm{H}, \mathrm{m}, \mathrm{H}-6^{\prime}\right), 3.52\left(1 \mathrm{H}, \mathrm{dd}, J_{1,2} 4.0 \mathrm{~Hz}, J_{2,3} 10.0\right.$, $\mathrm{Hz}, \mathrm{H}-2), 3.43\left(1 \mathrm{H}, \mathrm{t}, J_{3,4} 10.0 \mathrm{~Hz}, \mathrm{H}-4\right)$ ppm. ${ }^{13} \mathrm{C}-\mathrm{NMR}\left(125 \mathrm{MHz}, \mathrm{D}_{2} \mathrm{O}\right)$ 8: 103.9 (C-2"), 103.3 (C-2'), 92.9 (C-1), $80.6\left(C^{\prime}-5^{\prime}\right), 80.4\left(C^{\prime \prime} 5^{\prime \prime}\right), 77.4\left(C-4^{\prime \prime}\right), 76.9\left(C-3^{\prime \prime}\right), 76.4\left(C-3^{\prime}\right), 76.3\left(C-4^{\prime}\right), 72.1(C-3), 71.4(C-4), 71.1(C-5), 71.0$ (C2), 59.9 (C-1', C-1"), 34.2 (C-6), 33.5 (C-6'), 33.5 (C-6") ppm. HRMS (ESI): calcd. for $\mathrm{C}_{18} \mathrm{H}_{29} \mathrm{Br}_{3} \mathrm{O}_{13} \mathrm{Na}^{\prime \prime} 714.9035$, $716.9015[\mathrm{M}+\mathrm{Na}]^{+} ;$found $714.9053,716.9034$.

6,6', 6"'-Trichloro-6,6',6"-trideoxy-1-kestose $(7,0.032 \mathrm{~g}, 85 \%) .[\alpha]_{\mathrm{D}}=+26.6$ (c 1.0, MeOH). ${ }^{1} \mathrm{H}-\mathrm{NMR}(500 \mathrm{MHz}$, $\left.D_{2} \mathrm{O}\right) \delta: 5.36\left(1 \mathrm{H}, \mathrm{d}, J_{1,2} 4.0 \mathrm{~Hz}, \mathrm{H}-1\right), 4.26\left(1 \mathrm{H}, \mathrm{d}, J_{3^{\prime}, 4^{\prime}} 8.6 \mathrm{~Hz}, \mathrm{H}-3^{\prime}\right), 4.16\left(1 \mathrm{H}, \mathrm{d}, J_{3^{\prime \prime}, 4^{\prime \prime}} 8.6 \mathrm{~Hz}, \mathrm{H}-3^{\prime \prime}\right), 4.11-4.05$ $\left(3 \mathrm{H}, \mathrm{m}, \mathrm{H}-4^{\prime}, \mathrm{H}-4^{\prime \prime}, \mathrm{H}-5\right)$, 4.01-3.94 (2H, m, H-5' $\left.\mathrm{H}-5^{\prime \prime}\right)$, 3.89-3.73 (7H, m, H-6, H-6', H-6", H-1'a), 3.71-3.60 (4H, m, H-1'b, H-1", H-3), $3.52\left(1 \mathrm{H}, \mathrm{dd}, J_{1,2} 4.0 \mathrm{~Hz}, J_{2,3} 9.7 \mathrm{~Hz}, \mathrm{H}-2\right), 3.47\left(1 \mathrm{H}, \mathrm{t}, J_{3,4} 9.7 \mathrm{~Hz}, \mathrm{H}-4\right)$ ppm. ${ }^{13} \mathrm{C}-\mathrm{NMR}(125$

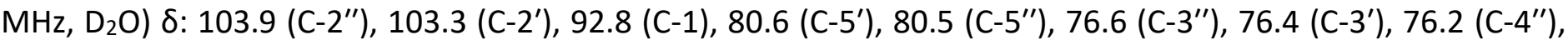
$75.3\left(\mathrm{C}-4^{\prime}\right), 72.2$ (C-3), 71.6 (C-4), 71.0 (C-5), 70.1 (C-2), $60.2\left(\mathrm{C}-1^{\prime}\right), 60.0\left(\mathrm{C}-1^{\prime \prime}\right), 45.4\left(\mathrm{C}-6^{\prime \prime}\right), 45.2\left(\mathrm{C}-6^{\prime}\right), 44.3$ (C6) ppm. HRMS (ESI): calcd. for $\mathrm{C}_{18} \mathrm{H}_{29} \mathrm{Cl}_{3} \mathrm{O}_{13} \mathrm{Na} 581.0571,583.0542$ [M + Na] ${ }^{+}$; found 581.0587, 583.0568.

\section{Acknowledgements}

Zetryana Puteri Tachrim thanks LPDP (Indonesia Endowment Fund for Education) for financial support. This research was partially supported by the Ministry of Education, Science, Sports, and Culture Grant-in-Aid for Scientific Research (C), (17K0194007 to Makoto Hashimoto). Part of this work was performed under the Cooperative Research Program of "Network Joint Research Center for Materials and Devices".

\section{Supplementary Material}

One- and two-dimensional nuclear magnetic resonance (1D and 2D NMR, respectively) figures for all synthetic compounds are available online. 


\section{References}

1. Ballesteros, A.; Plou, F. J.; Alcalde, M.; Ferrer, M.; Garcıa-Arellano, H.; Reyes-Duarte, D.; Ghazi, I. In Biocatalysis in the pharmaceutical and biotechnology industries; R.N. Patel, Ed.; CRC Press: Boca Raton, 2007; pp 463-488.

2. Vega, R.; Zúniga-Hansen, M. E. Bioresour. Technol., 2011, 102, 10180. https://doi.org/10.1016/i.biortech.2011.09.025

3. Calub, T. M.; Waterhouse, A. L.; Chatterton, N. J. Carbohydr. Res., 1990, 199, 11. https://doi.org/10.1016/0008-6215(90)84088-C

4. Siddiqui, I. R.; Purgala, B. J. Apic. Res., 1968, 7, 51. https://doi.org/10.1080/00218839.1968.11100188

5. Hammer, H. Acta Chem. Scand., 1968, 22, 197. https://doi.org/10.3891/acta.chem.scand.22-0197

6. Yun, J.W. Enzyme Microb. Technol., 1996, 19, 107. https://doi.org/10.1016/0141-0229(95)00188-3

7. Allen, P. J.; Bacon, J. S. D. Biochem. J., 1956, 63, 200. https://doi.org/10.1042/bj0630200

8. Hough, L.; Khan, R. Trends Biochem. Sci., 1978, 3, 61. https://doi.org/10.1016/S0968-0004(78)93998-1

9. Appel, R. Angew. Chem. Int. Ed., 1975, 14, 801. https://doi.org/10.1002/anie.197508011

10. Jarosz, S.; Mach, M. Eur. J. Org. Chem., 2002, 769. https://doi.org/10.1002/1099-0690(200203)2002:5<769::AID-EJOC769>3.0.CO;2-F

11. Kashem, A.; Anisuzzaman, M.; Whistler, R. L. Carbohydr. Res., 1978, 61, 511. https://doi.org/10.1016/S0008-6215(00)86063-2

12. Tachrim, Z. P.; Wang, L.; Yoshida, T.; Muto, M.; Nakamura, T.; Masuda, K.; Hashidoko, Y.; Hashimoto, M. ChemistrySelect, 2016, 1, 58. https://doi.org/10.1002/slct.201500003

13. Hough, L.; Richardson, A. C.; Salam, M. A. Carbohydr. Res., 1979, 71, 85. https://doi.org/10.1016/S0008-6215(00)86063-2

14. Lees, W. J.; Whitesides, G. M. J. Am. Chem. Soc. 1993, 115, 1860. https://doi.org/10.1021/ja00058a034

15. Pejin, B.; lodice, C.; Tommonaro, G.; Sabovljevic, M.; Bianco, A.; Tesevic, V.; Vajs, V. De Rosa, S. Nat. Prod. Res. 2012, 26, 209. https://doi.org/10.1080/14786419.2010.535163

16. Wang, L.; Hashidoko, Y.; Hashimoto, M. J. Org. Chem., 2016, 81, 4464 https://doi.org/10.1021/acs.joc.6b00144

17. Wang, L.; Tachrim, Z. P.; Kurokawa, N.; Ohashi, F.; Wakasa, H.; Sakihama, Y.; Hashidoko, Y.; Suzuki, T.; Hashimoto, M. Arkivoc, 2018, 7, 56. https://doi.org/10.24820/ark.5550190.p010.668

18. Binkley, W. W.; Horton, D.; Bhacca, N. S. Carbohydr. Res., 1969, 10, 245. https://doi.org/10.1016/S0008-6215(00)80466-8 